Research, Society and Development, v. 9, n. 8, e199985612, 2020

(CC BY 4.0) | ISSN 2525-3409 | DOI: http://dx.doi.org/10.33448/rsd-v9i8.5612

Estudo das propriedades nutricionais, sensoriais e microbiológicas de pastas alimentícias elaboradas com amêndoa de baru (Dipteryx alata vog.)

Study of the nutritional, sensory and microbiological properties of food pastes made with baru almonds (Dipteryx alata vog.)

Estudio de las propiedades nutricionales, sensoriales y microbiológicas de las pastas alimenticias elaboradas con almendra baru (Dipteryx alata vog.)

Recebido: 14/06/2020 | Revisado: 14/06/2020 | Aceito: 16/06/2020 | Publicado: 29/06/2020

Marina Leopoldina Lamounier Campidelli

ORCID: https://orcid.org/0000-0002-0127-2943

Universidade Federal de Lavras, Brasil

E-mail: marina.lamounier@yahoo.com.br

Maica de Paula Naves

ORCID: https://orcid.org/0000-0001-5448-2533

Universidade Federal de Lavras, Brasil

E-mail: maicapaula@hotmail.com

Grayce Kelly de Andrade

ORCID: https://orcid.org/0000-0001-5457-7161

Universidade Federal de Lavras, Brasil

E-mail: grayce_kelly_an@hotmail.com

João de Deus de Souza Carneiro

ORCID: https://orcid.org/0000-0003-4060-5891

Universidade Federal de Lavras, Brasil

E-mail: joaodedeus@ufla.br

Ellen Cristina de Souza

ORCID: https://orcid.org/0000-0002-3369-4892

Universidade Federal de Lavras, Brasil

E-mail: ellencsou@hotmail.com

Maísa Lamounier Magalhães

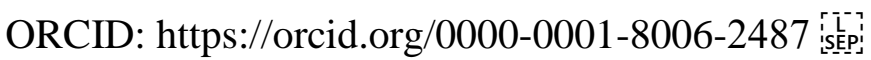

Universidade Federal de Lavras, Brazil

E-mail: maisalamounier@yahoo.com.br 


\section{Priscila Castellani Coli}

ORCID: https://orcid.org/0000-0002-6891-7347

Universidade Federal de Lavras, Brasil

E-mail: priscilaccoli@gmail.com

David Nelson Lee

ORCID: https://orcid.org/0000-0001-7435-3675

Universidade Federal do Vale do Jequitinhonha e Mucuri, Brasil

E-mail: dleenelson@gmail.com

Eduardo Valério de Barros Vilas Boas

ORCID: https://orcid.org/0000-0002-0252-695X

Universidade Federal de Lavras, Brasil

E-mail: evbvboas@dca.ufla.br

\section{Resumo}

A amêndoa de baru é uma oleaginosa nativa do bioma Cerrado e destaca-se devido seu elevado teor de nutrientes. O presente estudo teve como objetivo realizar uma caracterização centesimal, mineral, microbiológica e sensorial de pastas alimentícias elaboradas com diferentes teores de amêndoas baru, que foram: P1 (35\%); P2 (17.5\%); e P3 (0\%). Para contrabalancear as diferentes porcentagens de amêndoa, utilizou-se avelã, controle do experimento. As pastas alimentícias constituídas de 35\% de amêndoa de baru (P1) obtiveram os maiores valores de umidade, lipídeos, valor energético total e cálcio, no entanto, apesentaram redução nos teores de cinzas, proteínas e carboidratos. Já as pastas alimentícias elaboradas com 0\% de amêndoa de baru (P3) apresentaram superioridade nos teores de potássio e zinco, indicando que a avelã pode influenciar positivamente a presença desses minerais. Quanto aos resultados microbiológicos, constatou-se que todas as pastas desenvolvidas indicaram ausência de coliformes totais e à $45^{\circ} \mathrm{C}$ e obtiveram baixos níveis de bolores e leveduras nas diluições de $10^{-1}$ e $10^{-2} \mathrm{UFC} / \mathrm{g}$ e ausência em $10^{-3} \mathrm{UFC} / \mathrm{g}$. Para os atributos sensoriais de sabor, impressão global e intenção de compra, não foram observadas diferenças significativas entre as formulações, no entanto, observou-se que as pastas alimentícias constituídas de $17.5 \%$ de amêndoa de baru e $17.5 \%$ de avelã (P2) obtiveram as maiores notas para aparência e textura. Conclui-se que as pastas alimentícias elaboradas com diferentes teores de amêndoa de baru apresentaram características nutritivas, sensoriais e microbiológicas satisfatórias para o consumo. 
Palavras-chave: Cerrado; Oleaginosas; Desenvolvimento de novos produtos.

\begin{abstract}
Baru almond is an oilseed native to the Cerrado biome and stands out because of its large nutrient content. The present study sought to perform a centesimal, mineral, microbiological and sensory characterization of food pastes made with different contents of baru almonds: P1 (35\%); P2 (17.5\%); and P3 (0\%). Hazelnuts were used as the control to counterbalance the different percentages of almond. The highest concentrations of moisture, lipids, and calcium and the highest total energy value were observed with the food pastes consisting of $35 \%$ baru almond (P1). However, a decrease in ash, protein and carbohydrate contents occurred. Higher concentrations of potassium and zinc were found in the food pastes made with $0 \%$ baru almond (P3), indicating that hazelnuts contained a greater quantity of these minerals. As for the microbiological results, no coliforms were found for any of the pastes tested. Low levels of molds and yeasts were observed at the dilutions of $10^{-1}$ and $10^{-2} \mathrm{UFC} / \mathrm{g}$ and none at $10^{-3}$ UFC/g. For the taste sensorial attributes, global impression and intention to purchase, no significant differences were observed between the formulations. However, the food pastes consisting of $17.5 \%$ baru almond and $17.5 \%$ hazelnut $(\mathrm{P} 2)$ received the highest scores for appearance and texture. It is concluded that the food pastes made with different contents of baru almond had satisfactory nutritional, sensory and microbiological characteristics for consumption.
\end{abstract}

Keywords: Cerrado; Oilseeds; Development of new products.

\title{
Resumen
}

La almendra de Baru es una semilla oleaginosa nativa del bioma Cerrado y destaca por su alto contenido de nutrientes. El presente estudio tuvo como objetivo realizar una caracterización centesimal, mineral, microbiológica y sensorial de pastas alimenticias elaboradas con diferentes contenidos de almendras baru, que fueron: P1 (35\%); P2 (17.5\%); y P3 (0\%). Para contrarrestar los diferentes porcentajes de almendras, se utilizó avellana, control del experimento. Las pastas alimenticias que consisten en $35 \%$ de almendra baru (P1) obtuvieron los valores más altos de humedad, lípidos, valor energético total y calcio, sin embargo, mostraron una reducción en el contenido de cenizas, proteínas y carbohidratos. Ya las pastas alimenticias hechas con $0 \%$ de almendra baru (P3) mostraron superioridad en los niveles de potasio y zinc, lo que indica que la avellana puede influir positivamente en la presencia de estos minerales. En cuanto a los resultados microbiológicos, se encontró que todas las pastas desarrolladas indicaron la ausencia de coliformes totales y a $45{ }^{\circ} \mathrm{C}$ y obtuvieron niveles bajos de mohos y levaduras en las diluciones de $10^{-1}$ y $10^{-2} \mathrm{UFC} / \mathrm{gy}$ ausencia en $10^{-}$ 
${ }^{3}$ UFC/sol. Para los atributos sensoriales de sabor, impresión global e intención de compra, no se observaron diferencias significativas entre las formulaciones, sin embargo, se observó que se obtuvieron pastas alimenticias que consistían en $17.5 \%$ de almendra baru y $17.5 \%$ de avellana (P2) Las notas más altas en apariencia y textura. Se concluye que las pastas alimenticias hechas con diferentes contenidos de almendra baru tenían características nutricionales, sensoriales y microbiológicas satisfactorias para el consumo.

Palabras clave: Cerrado; Semillas oleaginosas; Desarrollo de nuevos productos.

\section{Introduction}

Brazil is widely recognized for the biodiversity of its forests, and it has hundreds of species that provide seeds, nuts and edible kernels with unique sensory characteristics that are appropriate for the development of new products (Carvalho et al., 2012). The baru almond (Dipteryx alata Vog.) is an oilseed native to the Cerrado biome and stands out because of its large nutrient content and high market value and because it is part of an abundant genetic heritage from the point of view of health. Previous studies performed with this almond have demonstrated the presence of important chemical and nutritive compounds, such as proteins, fibers, lipids, unsaturated fatty acids (linoleic and oleic), minerals, antioxidant molecules, polyphenols (catechin, rutin and gallic, caffeine, chlorogenic acids, $o$-cumárico and transcinnamic) and vitamins [(C and tocopherols (alpha and gamma)] (Lemos et al., 2012; Sano et al., 2014; Lemos et al., 2016; Campidelli et al., 2019; Campidelli et al., 2020).

Among the options for food products in which oilseeds are used, hazelnut pastes stand out. They are widely consumed because of their high degree of acceptance. However, these products generally contain high concentrations of sugars and low proportions of oilseeds, which impairs their consumption by those who wish to reduce caloric intake and obtain health benefits. Furthermore, hazelnuts are included in one of the main food groups responsible for triggering food allergies (Holzhauser, Stephan \& Vieths, 2002).

A viable alternative would be to substitute another oilseed, the baru almond, because its composition is superior to those of hazelnuts, and extra physiological health benefits can be obtained (Campidelli et al., 2020a; Oliveira-Alves et al., 2020). However, information that proves the effectiveness of these products for health must be scientifically attested, despite the fact that the vast majority remaining unexplored. The present study sought to perform a centesimal, mineral, microbiological and sensory of food pastes made with different contents of baru almonds to furnish information regarding the functional potential of baru almonds in 
new products, as well as identifying new nutritional properties of ready-to-eat products.

\section{Methodology}

A quantitative exploratory research as oriented by Pereira et al. (2018) was performed via laboratory experiments during the period from April to December of 2018.

The experiment was accomplished at the Fruit and Vegetable Post-Harvest and New Product Development Laboratories of the Federal University of Lavras, Lavras, MG, Brazil and was approved by the Ethics Committee of the Federal University of Rio Grande do Sul under the number 1716.605.

\section{Ingredients}

The following raw materials were used to manufacture food pastes: baru almonds (AB) (purchased from producers in the city of Barra do Garça, MT, Brazil), hazelnuts, erythritol, coconut oil (extra virgin), powdered skim milk, 100\% cocoa powder, polydextrose, whey, emulsifier and flavoring.

\section{Formulations}

Three different paste formulations were developed through the addition of different AB contents: paste with $35 \%$ baru almonds (P1); paste with $17.5 \%$ baru almonds $(\mathrm{P} 2)$; and control paste with $0 \%$ baru almonds (P3). Hazelnuts were used to counterbalance the different percentages of almonds (Table 1). The experimental design was two formulations plus control with three replications. 
Research, Society and Development, v. 9, n. 8, e199985612, 2020

(CC BY 4.0) | ISSN 2525-3409 | DOI: http://dx.doi.org/10.33448/rsd-v9i8.5612

Table 1. Formulation of pastes with different baru almond contents.

\begin{tabular}{lccc}
\hline & \multicolumn{3}{c}{ Formulations } \\
\cline { 2 - 4 } Ingredients (\%) & $\mathrm{P} 1$ & $\mathrm{P} 2$ & $\mathrm{P} 3$ \\
\hline Baru almond & 35 & 17.5 & 0 \\
Hazelnut & 0 & 17.5 & 35 \\
Erithritol & 29.5 & 29.5 & 29.5 \\
Coconut oil & 14 & 14 & 14 \\
Powdered skim milk & 5.6 & 5.6 & 5.6 \\
Cocoa 100\% & 10.4 & 10.4 & 10.4 \\
Polydextrose & 3 & 3 & 3 \\
Whey & 1 & 1 & 1 \\
Emulsifyer & 1 & 1 & 1 \\
Flavoring & 0.5 & 0.5 & 0.5 \\
\hline
\end{tabular}

Prepared by the authors

In Table 1, it is possible to verify the presence of the ingredients used for the manufacture of food pastes. Erythritol was the sweetener used to replace sugar, while powdered milk and polydextrose helped in the formation of texture and contributed with the addition of dietary fiber, respectively.

\section{Processing of pastes}

Initially, AB was dried in a forced air oven (Marconi, MA0351, Piracicaba, Brazil) at $105{ }^{\circ} \mathrm{C}$ for 30 minutes. The dried almonds were ground (experimental mill with mesh 20 , Viti Molinos, VG 2000i, Itajaí, Brazil), packed in transparent polyethylene containers and stored at $25^{\circ} \mathrm{C}$ in temperature-controlled chambers (Eletrolab, model EL202).

The previously prepared $\mathrm{AB}$ was homogenized with the other ingredients present in its formulation (Table 1) for 5 minutes (Philips Walita model Viva RI7630 processor) to prepare the food pastes (PA). After homogenization, the PA were packed in transparent polyethylene packages and stored at $-22^{\circ} \mathrm{C}$ (Eletrolab, model EL202).

\section{Characterization of products}

\section{Proximate composition}

The proximate composition was determined according to the method described by IAL 
(CC BY 4.0) | ISSN 2525-3409 | DOI: http://dx.doi.org/10.33448/rsd-v9i8.5612

(2008). The moisture content was estimated by means of direct heating in an oven with forced air at $105{ }^{\circ} \mathrm{C}$ until constant weight was obtained. The lipids were determined by the Soxhlet method through extraction with petroleum ether.

The crude protein was determined by digestion, followed by distillation of the ammonia in a Micro-Kjedahl apparatus, and using the factor 6.25 to calculate the protein concentration. The ash fraction was obtained gravimetrically, by weighing the residue obtained after heating the material at $550{ }^{\circ} \mathrm{C}$ in a muffle furnace. The total carbohydrate content was calculated by the difference obtained after subtracting the percentage of moisture, ash, lipids and proteins. The results were expressed in $\mathrm{g} .100 \mathrm{~g}^{-1}$. The total energy value (VET) was determined using the conversion factors determined in RDC $\mathrm{n}^{\circ} 40$ (Brasil, 2001).

\section{Microbiological analysis}

The total count of molds and yeasts was performed by surface plating according to the method of the American Public Health Association (APHA, 2001). The Dicloran Rosa Bengala-1-2-Chloramphenicol culture medium was used for counting, incubating at $25{ }^{\circ} \mathrm{C}$ for 7 days, with dilutions of $10^{-1}, 10^{-2}$ and $10^{-3}$. The results were expressed as the presence or absence of $\mathrm{CFU} / \mathrm{g}$.

The analysis of total and thermotolerant coliforms was performed according to APHA (2001) by sowing three series of tubes containing $9 \mathrm{~mL}$ of lauryl sulfate tryptose broth and an inverted Durhan tube with $1 \mathrm{~mL}$ of different sample dilutions. The tubes were incubated at 37 ${ }^{\circ} \mathrm{C}$ for 24 to 48 hours to check the formation of gas and turbidity of the medium, which indicated the presence of these microorganisms.

\section{Mineral composition}

The minerals were determined according to the method of Sarruge \& Haag (1974) by digestion with perchloric and nitric acid at $50{ }^{\circ} \mathrm{C}$ for 10 to 15 minutes and then at $100{ }^{\circ} \mathrm{C}$ to digest all the material. The reading was performed on an atomic absorption spectrophotometer at $248.3 \mathrm{~nm}$. The concentrations of phosphorus, potassium, calcium, zinc and iron were measured, and the results were expressed in mg. $100 \mathrm{~g}^{-1}$ of sample. 


\section{Sensorial analysis}

Ten-gram samples were served to a panel of 100 untrained tasters at a temperature of approximately $10{ }^{\circ} \mathrm{C}$. They were offered to participants in individual booths in a random arrangement to avoid the demand effect (Minim, 2013). Participants were asked to answer questions regarding acceptance of the product with respect to the attributes of flavor, appearance, texture and overall impression based on a structured hedonic scale of nine points (1= I really disliked it, up to $9=$ I really liked it).

They were also asked to respond to questions regarding the intention to purchase, using a hedonic scale of five points ( $1=\mathrm{I}$ would certainly not purchase, up to $5=\mathrm{I}$ would certainly purchase), and frequency of consumption of oil-based pastes, such as hazelnut pastes, peanut pastes and others.

\section{Statistical analysis}

The data were submitted to analysis of variance (ANOVA) and a test of comparison of means (Tukey, 5\% probability of error). Statistical calculations were performed using version 5.0 of the R program.

\section{Results and Discussion}

\section{Proximate composition}

The proximate composition of food pastes made with different baru almond contents can be seen in Table 2. 
Table 2. Mean values for the proximate composition of food pastes made with different quantities of baru almonds. ${ }^{(1)}$

\begin{tabular}{cccccccc}
\hline Formulation $^{2}$ & Moisture & Lipids & $\begin{array}{c}\text { Non-nitrogen } \\
\text { extract }^{3}\end{array}$ & Ash & Fiber & Protein & VET $^{4}$ \\
\hline P1 & $2.93 \pm 0.40^{\mathrm{a}}$ & $53.29 \pm 4.28^{\mathrm{a}}$ & $31.3 \pm 1.32^{\mathrm{c}}$ & $3.15 \pm 0.27^{\mathrm{b}}$ & $2.65 \pm 0.01^{\mathrm{a}}$ & $6.7 \pm 0.06^{\mathrm{b}}$ & $632 \pm 0.83^{\mathrm{a}}$ \\
P2 & $2.5 \pm 0.49^{\mathrm{b}}$ & $40.60 \pm 0.032^{\mathrm{b}}$ & $43 \pm 0.93^{\mathrm{a}}$ & $3.37 \pm 0.73^{\mathrm{a}}$ & $2.98 \pm 0.04^{\mathrm{a}}$ & $7.7 \pm 0.83^{\mathrm{a}}$ & $568 \pm 1.03^{\mathrm{b}}$ \\
P3 & $2.47 \pm 2.62^{\mathrm{b}}$ & $37.95 \pm 3.21^{\mathrm{c}}$ & $47 \pm 0.73^{\mathrm{a}}$ & $3.35 \pm 0.03^{\mathrm{a}}$ & $1.42 \pm 0.42^{\mathrm{b}}$ & $7.7 \pm 0.53^{\mathrm{a}}$ & $560 \pm 1.93^{\mathrm{b}}$ \\
\hline
\end{tabular}

Notes: ${ }^{1}$ Data are presented as mean \pm standard deviation and are expressed in $\mathrm{g} .100 \mathrm{~g}^{-1}$, except for VET which is expressed as kcal.100 $\mathrm{g}^{-1}$; ${ }^{2}$ Formulations: $\mathrm{P} 1=$ paste with $35 \%$ baru almond and $0 \%$ hazelnut; $\mathrm{P} 2$ = paste with $17.5 \%$ baru almond and $17.5 \%$ hazelnut; P3 = control paste with $0 \%$ baru almond and $35 \%$ hazelnut. ${ }^{3}$ Calculated from the difference of 100 minus the sum of the percentages of ash, lipids, protein and moisture; ${ }^{4}$ Values determined using the conversion factors determined in the DRC number 40 (Brasil, 2001).

The moisture contents of the food pastes were considered to be low (less than $3 \%$. They were below the maximum limit of $15 \%$ established by the legislation for cereal products (ANVISA, 1978).

The P1 formulation differed statistically from the others $(\mathrm{p}<0.05)$; its moisture content was higher. Nevertheless, the moisture contents of all the formulations were favorable for the conservation of the products because high concentrations of water can favor the proliferation of microorganisms and chemical reactions.

In research by Lubas et al. (2016), who developed chocolate bars containing 35\% baru almonds, it was also found that the higher the percentages of this almond, the higher the moisture content present, which is similar to the results obtained in this work.

A decrease of 23.81 and $28.78 \%$ in total lipids was detected according to the respective decrease in the amount of baru almond in formulations P2 and P3. According to Campidelli et al. (2019), baru almonds contains $31.73 \%$ lipids, it being one of the oilseeds with the highest fat content.

Considering that the intake of this macronutrient is important for the nutritional balance of the human organism, it is estimated that the presence of $\mathrm{AB}$ can contribute good quality lipids to the paste.

The results agree with those published by Soares et al. (2018), who, when preparing cookies enriched with 10 and $20 \%$ baru almond flour, found lipid contents close to 25.15 and $26.72 \%$. The notable increase in this value was proportional to the increase in the concentration of baru almond flour.

It was found that the concentrations of carbohydrates in formulas P2 and P3 were statistically similar ( $p>0.05)$ and corresponded to the highest values. This fact indicates that 
hazelnut can be responsible for the significant increase in this macronutrient, compared to that obtained with baru almonds.

Despite this difference, a high concentration of carbohydrates can be attributed to all the formulations so these products can be considered to be adequate sources of energy. Furthermore, the Recommended Daily Intake (RDI) for this nutrient is set at 300 grams per day (Brasil, 2005) and, therefore, the consumption of 100 grams of P1, P2 and P3, can furnish $10.4 \%, 14.3 \%$ and $15.6 \%$, respectively, of that intake.

Food pastes can contain high levels of carbohydrates, which are an immediate source of energy for the body. Despite the importance of this nutrient to the functioning of the body, it is important to note that excessive consumption has been associated with adverse effects.

The ash contents of formulas P2 and P3 were statistically equal ( $p>0.05)$, and they contained higher levels of minerals than $\mathrm{P} 1$. The hazelnut probably contains greater quantities of this nutrient than the baru almond. Despite these findings, it is estimated that all the values were high and can be beneficial for health, given that these components perform structural and biological functions essential to the functioning of the human organism.

In research by Rinaldi et al. (2016), who developed baru-based cereal bars, an average value of $1.57 \mathrm{~g}$ of ash/100 $\mathrm{g}$ was found. In the work of Soares et al. (2018), 2.42 and $2.86 \mathrm{~g}$ of ash.100 $\mathrm{g}^{-1}$ were found in cookies formulated with $10 \%$ and $20 \%$, respectively, of baru almond flour.

The fiber contents of formulas P1 and P2 were statistically equal ( $p>0.05$ ), and they also contained the greatest amount of fiber, followed by formula P3. The DRI of this nutrient is $30 \mathrm{~g}$ per day (ANVISA, 2016), and the consumption of 100 grams of P1, P2 and P3 pastes corresponds to $8.83,9.93$ and $4.73 \%$ of the DRI, respectively.

These results demonstrate that the presence of baru almonds in food pastes can positively influence the presence of this macronutrient because fibers are important agents that influence the intestinal microbiota by modulating it positively.

These results are in line with those found by Junior et al. (2007), who found increasing values for fiber, which were $0.48,0.83,1.15$ and $1.49 \%$, respectively, when they developed cookies containing different quantities of almond flour (2, 4, 6 and 8\%). This increase also occurred in the cookies formulated by Soares et al. (2018), who found fiber percentages of 4.9 and $7.81 \%$ when they added 10 and $20 \%$ baru almond flour, respectively.

The protein contents of formulas P2 and P3 were greater than those found in P1, and they were statistically similar ( $\mathrm{p}>0.05)$. P1, P2 and P3 food pastes represent 13.4, 15.4 and 
$15.4 \%$ of the DRI for this nutrient, which is $50 \mathrm{~g} .100 \mathrm{~g}^{-1}$ for adults, respectively (BRASIL, 2005).

According to the Brazilian legislation (Brasil, 2012), which determines that foods that are sources of protein should contain a minimum of $6 \mathrm{~g}$ of protein per $100 \mathrm{~g}$ of product. These results have recognized merit because these macronutrients contribute to the development of body structures and aid in nutrition.

The highest caloric content $(\mathrm{p}<0.05)$ was found in formula P1, followed by P2 and P3, which were statistically equal ( $p>0.05)$. This result is compatible with the quantities of lipids found because the greater the fat content, the greater the energy content. Furthermore, the consumption of 100 grams of P1, P2 and P3 food pastes represents 31.15, 28.4 and 26\% of the Daily Reference Values (DRV), respectively (Brasil, 2003).

These pastes are considered to be foods with a high caloric content, and it is recommended that daily consumption not be excessive. Rinaldi et al. (2016) found an average value of $491.64 \mathrm{Kcal} 100 \mathrm{~g}^{-1}$, a result close to that of this study, when they prepared barubased cereal bars.

\section{Microbiological analysis}

The results of the microbiological analysis of food pastes made with different quantities of baru almonds are described in Table 3.

Table 3. Microbiological analyses for the presence of total and thermotolerant coliforms and the counting of molds and yeasts in food paste made with different quantities of baru almonds. ${ }^{(1)}$.

\begin{tabular}{|c|c|c|c|c|c|}
\hline \multirow[b]{2}{*}{ Formulation $^{2}$} & \multirow[b]{2}{*}{ Total coliforms $(\mathrm{MPN} / \mathrm{g})^{3}$} & \multirow[b]{2}{*}{$\begin{array}{c}\text { Coliforms } \\
45^{\circ} \mathrm{C}(\mathrm{MPN} / \mathrm{g})^{3}\end{array}$} & \multicolumn{3}{|c|}{ Molds and Yeast } \\
\hline & & & $\begin{array}{c}10^{-1} \text { Dilution } \\
\mathrm{CFU} / \mathrm{g}\end{array}$ & $10^{-2}$ Dilution CFU/g & $10^{-3}$ Dilution CFU/g \\
\hline P1 & Absent & Absent & 17 & 2 & 0 \\
\hline $\mathrm{P} 2$ & Absent & Absent & 14 & 8 & 0 \\
\hline P3 & Absent & Absent & 8 & 2 & 0 \\
\hline
\end{tabular}

Notes: ${ }^{1}$ Data are presented as means; ${ }^{2}$ Formulations: $\mathrm{P} 1=$ paste with $35 \%$ baru almond and $0 \%$ hazelnut; $\mathrm{P} 2=$ paste with $17.5 \%$ baru almond and $17.5 \%$ hazelnut; $\mathrm{P} 3=$ control paste with $0 \%$ baru almond and 35\% hazelnut; ${ }^{3}$ MPN: Most probable number (Apha, 2001).

According to RDC Resolution No. 12 of January 2001 from the National Health Surveillance Agency (ANVISA, 2001), which monitors and determines microbiological and sanitary standards for almond-based plant products, the values for coliforms at $45{ }^{\circ} \mathrm{C}$ must be 
lower than $10 \mathrm{MPN} / \mathrm{g}$. In this work, all the formulations were adapted to the recommendations, no microorganism was found.

There are no established criteria in the Brazilian Food Law (ANVISA, 2001) regarding the total count of molds and yeasts in almonds. However, the low count is important information for obtaining and supplying products with adequate microbiological quality.

Low levels of molds and yeasts in the dilutions of $10^{-1}$ and $10^{-2} \mathrm{CFU} / \mathrm{g}$ and an absence in $10^{-3} \mathrm{CFU} / \mathrm{g}$ were observed, showing that the hygiene and quality control techniques were satisfactory during the process of preparation of the food pastes.

Therefore, the results of both analyses indicate that there were no hygienic flaws that could compromise microbiological safety during the stages of preparation, packaging and storage of the foods, demonstrating sanitary quality in all the stages of production.

\section{Mineral composition}

The concentrations of potassium, phosphorus, calcium, zinc and iron present in food pastes made with different levels of baru almonds, as well as the DRI, are shown in Table 4.

Table 4. Determination of the mineral composition $\left(\mathrm{mg} .100 \mathrm{~g}^{-1}\right)$ of the pastes and DRI. ${ }^{(1,2)}$

\begin{tabular}{|c|c|c|c|c|c|}
\hline Formula $^{(3)}$ & Potassium (K) & Phosphorus (P) & Calcium $(\mathrm{Ca})$ & Zinc $(\mathrm{Zn})$ & Iron $(\mathrm{Fe})$ \\
\hline $\mathrm{P} 1$ & $9600 \pm 0.47^{\mathrm{c}}$ & $4100 \pm 0.89^{\mathrm{a}}$ & $3500 \pm 0.08^{\mathrm{a}}$ & $35.1 \pm 0.86^{\mathrm{c}}$ & $125.9 \pm 0.09^{a}$ \\
\hline $\mathrm{P} 2$ & $10000 \pm 0.78^{b}$ & $4000 \pm 0.59^{\mathrm{a}}$ & $2500 \pm 0.87^{b}$ & $40.6 \pm 0.34^{\mathrm{b}}$ & $132.4 \pm 0.54^{\mathrm{a}}$ \\
\hline P3 & $10300 \pm 0.67^{\mathrm{a}}$ & $3600 \pm 0.90^{\mathrm{b}}$ & $2300 \pm 0.75^{b}$ & $43.2 \pm 0.56^{\mathrm{a}}$ & $106.4 \pm 0.97^{b}$ \\
\hline $\operatorname{DRI}\left(\mathrm{mg} / 100 \mathrm{~g}^{-1}\right)$ & 3510 & 700 & 1000 & 7 & 14 \\
\hline$P$ value & 0.0045 & 0.0127 & 0.0004 & 0.0000 & 0.0000 \\
\hline
\end{tabular}

Notes: ${ }^{1}$ Means followed by distinct letters in the columns differ from each other by the Tukey test (p<0.05); ${ }^{2}$ DRI: Recommended Daily Intake (Brasil, 2005); ${ }^{3}$ Formulations: P1= paste with $35 \%$ baru almond and $0 \%$ hazelnut; $\mathrm{P} 2=$ paste with $17.5 \%$ baru almond and $17.5 \%$ hazelnut; $\mathrm{P} 3=$ control paste with $0 \%$ baru almond and $35 \%$ hazelnut. Source: Prepared by the authors.

A significant difference $(\mathrm{p}<0.05)$ was observed for the minerals analyzed, demonstrating that the variation in oilseeds resulted in differences in these elements. It was found that the higher the baru (P1) almond content, the higher the concentrations of phosphorus, calcium and iron. With respect to phosphorus and iron present in formulation P2, the concentrations of these elements are significantly similar to those of P1 ( $>0.05)$, indicating that the use of $17.5 \%$ baru almond and $17.5 \%$ hazelnut can provide the same result as that obtained when using $35 \%$ baru almond (P1).

As for the P3 formulation containing exclusively hazelnut, its use resulted in an increase in the levels of potassium and zinc $(\mathrm{p}<0.05)$. Regardless of the oilseed used, high values for 
Research, Society and Development, v. 9, n. 8, e199985612, 2020

(CC BY 4.0) | ISSN 2525-3409 | DOI: http://dx.doi.org/10.33448/rsd-v9i8.5612

mineral content that exceeded those recommended by the DRI were found for all the food paste formulations, and they are classified as foods with high mineral contents (Brasil, 2005).

\section{Sensorial analysis}

The frequency of consumption of oil-based pastes was verified, and the following information was observed: $45 \%$ of the tasters consume this type of product twice a month; $41 \%$ do not consume it; $11 \%$ consume only once a week; $2 \%$ consume more than twice a week; and $1 \%$ consume twice a week. Thus, the vast majority of respondents are accustomed to consuming this type of product; on the other hand, the other majority of respondents do not consume them. The non-consumption can be justified mainly by the high cost of these foods, and it is likely that the percentage of consumers adhering to this category of foods will increase if the nutritional benefits they present are divulged.

Regarding the sensory descriptors (Figure 1), scores greater than 7.0 were obtained for all the formulations, demonstrating an adequate acceptability of the products by the tasters. However, when analyzed individually, it was clear that the P2 formulation differed significantly $(p<0.05)$ from the other formulations with regard to appearance and texture. There was no difference ( $p>0.05$ ) between formulations P1, P2 and P3 regarding flavor and global impression; that is, the percentages of these oilseeds used did not make a significant difference to the tasters ( $p>0.05$ ), demonstrating that baru almond, little known and infrequently consumed, can sensorially resemble an oil that is frequently consumed (hazelnut). 
Figure 1. Frequency of consumption, scores for sensory acceptance and intention to purchase for food pastes made with different baru almond contents. ${ }^{(1) .}$

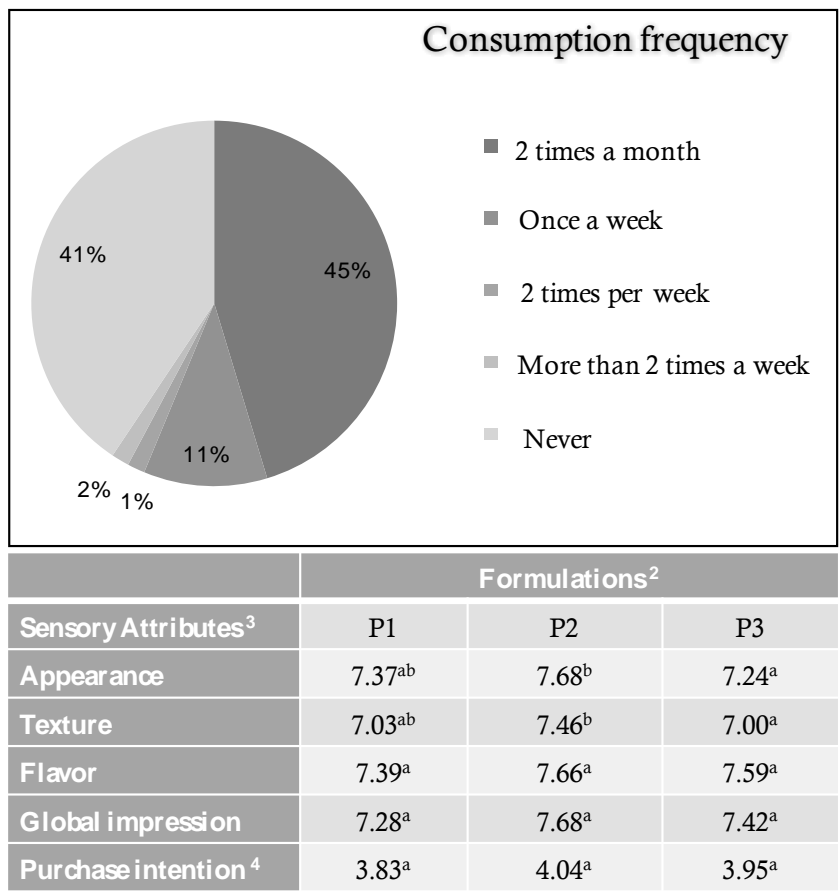

Notes: ${ }^{1}$ Means with different letters for the same analysis differ from each other $(\mathrm{p}<0.05)$; ${ }^{2}$ Formulations: $\mathrm{P} 1=$ paste with $35 \%$ baru almond and $0 \%$ hazelnut; $\mathrm{P} 2=$ paste with $17.5 \%$ baru almond and $17.5 \%$ hazelnut; $\mathrm{P} 3=$ control paste with $0 \%$ baru almond and $35 \%$ hazelnut; ${ }^{3} \mathrm{~A}$ 9-point scale was used; ${ }^{4} \mathrm{~A} 5$-point scale was used. Elaborated by the authors.

Regarding the intention to purchase, the evaluators demonstrated that "they might buy" the products if they were available for sale. Moreover, no significant differences were observed between the formulations $(p>0.05)$. In general, the food pastes pleased the consumers; however, they felt insecure regarding purchase.

The use of the baru almond, which is not commonly used in commercial products, might be one of the factors responsible for the indecision at the time of purchase. Because the pastes obtained satisfactory sensory acceptability, insecurity at the time of purchase can be minimized through marketing campaigns.

\section{Final Considerations}

The highest values for moisture, lipids, total energy and calcium were found in the food pastes consisting of $35 \%$ baru almonds (P1). However, the ash, protein and carbohydrate contents were lower. The food pastes made with $0 \%$ baru almonds (P3) contained higher levels of potassium and zinc, indicating that hazelnut contributes significantly to the presence of these minerals. As for the microbiological results, it was found that all the pastes developed 
(CC BY 4.0) | ISSN 2525-3409 | DOI: http://dx.doi.org/10.33448/rsd-v9i8.5612

contained no total coliforms at $45^{\circ} \mathrm{C}$. The levels of molds and yeasts in the dilutions of $10^{-1}$ and $10^{-2} \mathrm{CFU} / \mathrm{g}$ were low, and none were observed at $10^{-3} \mathrm{CFU} / \mathrm{g}$. Thus, the techniques of hygiene and quality control were satisfactory in their preparation.

For the sensory attributes of taste, global impression and intention to purchase, no significant differences were observed between the formulations; however, the food pastes consisting of $17.5 \%$ baru almonds and $17.5 \%$ hazelnut $(\mathrm{P} 2)$ received the highest scores for appearance and texture. It was concluded that the food pastes made with different baru almond contents possessed satisfactory nutritional, sensory and microbiological characteristics for consumption, which means that the products developed are of nutritional value.

\section{Financial support}

This work was funded by the CNPq (304724 / 2013-01), FAPEMIG (CAG-APQ00798-16 and PPM-00458-15) and CAPES (Procad - 88881.06.8456 / 2014-01).

\section{References}

Agência Nacional Vigilância Sanitária (1978). Resolução CNNPA $n^{o}$ 12, de 24 de julho de 1978. Aprova as seguintes normas técnicas especiais do Estado de São Paulo, revisadas pela CNNPA, relativas a alimentos (e bebidas) para efeito em todo o território brasileiro. Diário Oficial da República Federativa do Brasil.

Agência Nacional de Vigilância Sanitária. (2001). Resolução $R D C n^{o} 12$, de 02 de janeiro de 2001. Aprova o Regulamento Técnico sobre Padrões Microbiológicos para Alimentos. Diário Oficial da República Federativa do Brasil.

Agência Nacional De Vigilância Sanitária (2016). Lista dos Alimentos com Alegações de Propriedade Funcional e ou de Saúde. Diário Oficial da República Federativa do Brasil.

American Public Health Association (2001). Compendium of methods for the microbiological examination of foods. Washington: APHA. 
Brasil (2003). Ministério da Saúde. Resolução RDC n 360, de 23 de dezembro de 2003. Aprova o regulamento técnico sobre rotulagem nutricional de alimentos embalados. Diário Oficial da República Federativa do Brasil.

Brasil (2005). Ministério da Saúde. Resolução RDC $n^{\circ}$ 269, de 22 de setembro de 2005. Aprova o regulamento técnico sobre a ingestão diária de recomendada (IDR) de proteína, vitaminas e minerais. Diário Oficial da República Federativa do Brasil.

Brasil (2012). Ministério da Saúde. Resolução RDC $n^{\circ}$ 54, de 12 de novembro de 2012. Aprova o Regulamento Técnico referente à Informação Nutricional Complementar. (Declarações relacionadas ao conteúdo de nutrientes). Diário Oficial da República Federativa do Brasil.

Campidelli, M. L. L., Carneiro, J. D. S., Sousa, E. C., Magalhães, M.L., Nunes, E. E. C., Faria, P. B., Franco, M., \&Vilas Boas, E. V. B. (2020). Fatty acids, phenolic profile, tocopherols and antioxidants activity of baru almonds (Dipteryx alata Vog.): effects of drying process. Grasas y Aceites, 71(1), e343.

Campidelli, M. L. L., Carneiro, J. D. S., Sousa, E. C. S., Magalhães, M. L., Konig, I. F. M., Braga, M. A., Orlando, T. M., Simão, S. D., Lima, L. M. Z., \& Vilas Boas, E. V. B. (2019). Impact of the Drying Process on the Quality and Physicochemical and Mineral Composition of Baru Almonds (Dipteryx alata Vog.) Impact of the Drying Process on Baru Almonds. Journal of culinary science \& technology, 00(00), 1-13

Carvalho, I. M. M., Queirós, L. D., Brito, L. F., Santos, F. A., Bandeira, A. V. M., Souza, A. L., \& Queiroz, J. H. (2012). Chemical Characterization of Sapucaia Nuts (Lecythis pisonis Cambess.) from zona da Mata Mineira region. Bioscience Journal, 28(6), 971-977.

Holzhauser, T., Stephan, O., \& Vieths, S. (2002). Detection of potentially allergenic hazelnut (Corylus avellana) residues in food: a comparative study with DNA PCR ELISA and protein sandwich-ELISA. Journal of agricultural and food chemistry, 50(21), 5808-5815.

Instituto Adolf Lutz (2008). Métodos físico-químicos para análise de alimentos. São Paulo: Instituto Adolfo Lutz. 
Júnior, M. S., Caliari, M., Torres, M. C. L., Vera, R., Teixeira, J. S., \& Alves, L. C. (2007). Qualidade de biscoitos formulados com diferentes teores de farinha de amêndoa de baru (Dipteryx alata Vog.). Pesquisa Agropecuária Tropical (Agricultural Research in the Tropics), 37(1), 51-56.

Lemos, M. R. B., Siqueira., E. M. A., Arruda, S. F., \& Zambiazi, R. C. (2012). The effect of roasting on the phenolic compounds and antioxidant potential of baru nuts [Dipteryx alata Vog.]. Food Research International, 48(2), 592-597.

Lubas, S. C. C., Cândido, J. C., Souza, S. V. S., \& Guimarães, A. C. R. (2016). Qualidade nutricional de barras de chocolate adicionadas de castanhas de baru. Multitemas, 21(49) 181192.

Minim, V. P. R. (2013). Análise sensorial: estudo com consumidores. Viçosa: Editora da UFV.

Oliveira-Alves, S. C., Pereira, R. S., Pereira, A. B., Ferreira, A., Mecha, E., Silva, A. B., Serra, A. T., \& Bronze, M. R. (2020). Identification of functional compounds in baru (Dipteryx alata Vog.) nuts: Nutritional value, volatile and phenolic composition, antioxidant activity and antiproliferative effect. Food Research International, 131(0), 1-15.

Pereira, A. S., Shitsuka, D. M., Parreira, F. J. \& Shitsuka, R. (2018). Metodologia da pesquisa científica. [e-book]. Santa Maria: Ed. UAB/NTE/UFSM.

Rinaldi, M. M., Teixeira, L.P., Melo, R. A. C, Teixeira, M. F. N., \& Ishizawa, T. A. (2016). Desenvolvimento, Vida Útil e Custo de Produção de Barra de Cereal Formulada à Base de Baru (Dypterix alata Vog.). Brasília: Embrapa Cerrados-Boletim de Pesquisa e Desenvolvimento.

Sano S. M., Ribeiro J. F. \& Brito M. A. (2004). Baru: biologia e uso. Planaltina: Embrapa Cerrados.

Sarruge J. R., \& Haag H. P. (1974). Análises químicas em plantas. Piracicaba: Esalq. 
Soares V. L. (2018). Elaboração e Caracterização de Biscoitos Enriquecidos com Farinha de Amêndoa de Baru (Dissertação de mestrado). Universidade Federal dos Vales do Jequitinhonha e Mucuri - UFVJM, Diamantina, MG, Brasil.

\section{Percentage of contribution of each author in the manuscript}

Marina Leopoldina Lamounier Campidelli - 12\%

Maica de Paula Naves - $11 \%$

Grayce Kelly de Andrade - 11\%

João de Deus de Souza Carneiro - 11\%

Ellen Cristina de Souza - 11\%

Maísa Lamounier Magalhães - 11\%

Priscila Castellani Coli $-11 \%$

David Nelson Lee - $11 \%$

Eduardo Valério de Barros Vilas Boas - 11\% 